\title{
My Heart, My Mind, My Life: A Study on the Relation between Spiritual Well-being and Quality of Life in Heart Disease Patients
}

\section{Diah Nurayu Kusumawardani ${ }^{\mathrm{a}}$ and Sali Rahadi Asih $^{\mathrm{b}}$}

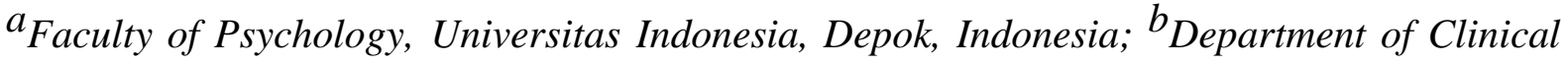
Psychology, Faculty of Psychology, Universitas Indonesia, Depok, Indonesia

*Corresponding author:

Sali Rahadi Asih

Department of Clinical Psychology

Faculty of Psychology, Universitas Indonesia

Jl. Lkr. Kampus Raya, Depok, Jawa Barat

Indonesia, 16424

Tel.: +62 217270004

Email address: sali.rahadi@ui.ac.id / sali.asih@gmail.com 


\title{
My Heart, My Mind, My Life: A Study on the Relation between Spiritual Well-being and Quality of Life in Heart Disease Patients
}

\begin{abstract}
Studies have shown that heart disease affects an individual's health-related quality of life (HRQoL). Two factors have been found to influence HRQoL: spiritual well-being and illness perception. Based on the literature review, spiritual well-being affects how patients evaluate their illness, which then shapes HRQoL. It is postulated that spiritual well-being affects illness perception, which in turn affects HRQoL. This study aims to investigate whether illness perception is a significant mediator of the relation between spiritual well-being and HRQoL. This research involved 44 heart disease patients in Jakarta and the suburbs of the Jakarta region. Mediation analysis results showed that illness perception has a partial mediating effect on the relation between spiritual well-being and HRQoL.
\end{abstract}

Keywords- HRQoL, illness perception, spiritual well-being

\section{Introduction}

Chronic illnesses affect people in many ways. One issue here is that chronic illness negatively influences people's health-related quality of life (HRQoL), which in turn significantly affects mental health. Research has shown that higher HRQoL leads to lower depression. Thus, HRQoL focuses not only on patients' mental health but also on how they perceive their physical condition (Guyatt, Feeny, \& Patrick, 1993). Guyatt et al. (1993) stated that one's mental health condition is shaped by external factors such as restriction to freedom, financial issues, or health problems. These external factors increase patients' anxiety and lead to negative emotions, which can prevent them from reaching optimum HRQoL. Anxiety and negative emotions produce mental health problems, which can diminish patients' HRQoL. Research by Moryś, Bellwon, Höfer, Rynkiewicz, and Gurchala (2016) has shown that heart disease patients who experience depression have lower HRQoL scores than those without depressive symptoms. Based on that study, HRQoL is said to greatly contribute to the alleviation of depression in heart disease patients.

HRQoL not only reduces depression but also brings more meaning into patients' lives. When they have high HRQoL, they have a positive outlook regarding their physical and mental state. This condition enables them to achieve a satisfactory life and self-realization (Gierlaszynska, Pudlo, Jaworska, Byrczek-Godula, K., \& Gąsior, 2016). For heart disease patients, HRQoL is of utmost importance because it reflects how they perceive their health (Thompson \& Yu, 2003). Such perception reflects their mental and physical condition. Two variables - spiritual wellbeing and illness perception - are therefore postulated to play a role in increasing HRQoL (Cella, 1994; Heo, Lennie, Okoli, \& Moser, 2009; Panzini et al., 2017).

Ellison (1983) provided two dimensions of spiritual well-being: the vertical dimension, which measures one's relationship with God, and the horizontal dimension, which realizes a person's meaning of life. When patients are diagnosed with chronic illness, they tend to be in denial of the situation. They even blame themselves for what happened. Patients find it difficult to accept 
their state, and they become anxious, which in turn causes depressive symptoms. Spiritual wellbeing can help patients overcome their anxiety and depression (Mills et al., 2015; Park et al., 2016) and significantly affects HRQoL. Some studies have found a significant relation between spiritual well-being and HRQoL (Jahani et al., 2013; Park, Lim, Newlon, Suresh, \& Bliss, 2014; Pilger, Santos, Lentsck, Marques, \& Kusumota, 2017). Improving patients' spiritual well-being would make them feel they are emotionally supported. In addition, patients' self-esteem and optimism tend to increase when they have high spiritual well-being (Petrie \& Weinman, 2006; Schnall et al., 2010). They also easily accept their condition because of their positive perception of their illness (Boyd et al., 2004).

The relation between spiritual well-being and HRQoL is shaped by the illness perception factor. Illness perception refers to patients' beliefs about their illness (Petrie \& Weinman, 2006). This may be defined as the way they evaluate their illness, whether or not such outlook is threatening. Studies found that spiritual well-being has a significant impact on patients' illness perception (Arnold, Herrick, Pankratz, \& Mueller, 2007; Reig-Ferrer et al., 2012; Büssing, Janko, Baumann, Hvidt, \& Kopf, 2013). Previous research has shown that the higher the spiritual wellbeing, the less threatening the perception of illness. Faith and acceptance, which are spiritual well-being components, lead patients to a more positive evaluation of their illness.

Illness perception also significantly contributes to HRQoL (Stafford, Berk, \& Jackson, 2009; Goodman, Firouzi, Banya, Lau-Walker, \& Cowie, 2013). When patients perceive their illness positively, they do not focus on the negative consequences of their illness. They only concentrate on how they can better improve their health condition through treatment or regular medication. Because they focus on their improvement, they never feel anxious or get depressed. This indicates a good mental state, which can in turn affect their HRQoL.

This study seeks to prove whether illness perception is a significant mediator for the relation between spiritual well-being and HRQoL. According to the literature, such relation had been dominated by patients' mental state. Yet spiritual well-being can help patients improve their perception of their illness. This study intends to elucidate whether illness perception significantly contributes to the spiritual well-being-HRQoL relation. Illness perception is expected to be a significant mediator here.

\section{Methods}

\section{A. Participants and Procedures}

This research involved 44 patients (Table 1$)(M$ age $=49.5, S D=17.44)$ who had already been diagnosed with heart disease. The participants had to be 18 years old or older and have had heart disease for at least a year. Questionnaires were given to these heart disease patients through the researchers' friends, family, and colleagues. The researchers also sought permission from the Sukmajaya Public Health Center (Pusat Kesehatan Masyarakat Sukmajaya) in Depok, a suburb near Jakarta, to meet some participants. 
All the patients were assessed for HRQoL, illness perceptions, and spiritual well-being using validated measurements, all of which were previously adapted to Bahasa Indonesia. Patients filled out a set of self-report questionnaires and were given small tokens for their involvement in this research. Before filling out all the questionnaire items, the patients were asked to participate in this study. They signed an informed consent form if they agreed.

\section{B. Measurements}

HRQoL was measured using SF-12 (Ware Jr., Kosinski, \& Keller, 1996) ("Secara umum, bagaimana Anda menggambarkan kondisi kesehatan Anda"; "Apakah kondisi kesehatan Anda membatasi Anda dalam melakukan aktivitas tersebut"). Subsequently, this study used Brief IPQ (Broadbent, Petrie, Main, \& Weinman, 2006), which was adapted to Bahasa Indonesia. Eight items measured patients' illness perception. Patients chose a number which corresponds to their evaluation of their illness ("Seberapa besar penyakit Anda memengaruhi hidup Anda"; "Menurut Anda, berapa lama penyakit Anda akan berkelanjutan"). Next, participants were asked to fill out FACIT-Sp to measure their spiritual well-being (Webster, Cella, \& Yost, 2003). This measure contained 12 items that assess patients' spirituality through a five-point Likerttype scale ( 1 = Never, 5 = Always) ("Saya merasa damai"; "Saya memiliki alasan untuk hidup").

\section{Data Analysis}

We used mediation analysis to test our hypothesis using the PROCESS macro in IBM Statistics version 20. The illness perception factor was put in as a mediator variable to see its role in the spiritual well-being-HRQoL relation. Illness perception was anticipated to significantly mediate in this relation.

\section{Results}

According to the mediation analysis results, spiritual well-being is significantly negatively correlated to illness perception $(\beta=-0.0391, S E=0.0187, t=-2.0962, p<0.05$, lower-level confidence interval $=-0.0768$, upper-level confidence interval $=-0.0015$ ). This indicates that the higher the spiritual well-being, the less the patients perceive their illness as threatening. Between illness perception and HRQoL, a strong negative relation was observed $(\beta=-4.7772$, $S E=2.2069, t=-2.1646, p<0.05$, lower-level confidence interval $=-9.2342$, upper-level confidence interval $=-0.3201$ ). This means that the less the patients perceive their illness as threatening, the higher their HRQoL. Spiritual well-being was also found to be a predictor of HRQoL $(\beta=0.8993, S E=0.2783, t=3.2313, p<0.05$, lower-level confidence interval = 0.3376 , upper-level confidence interval $=1.4610$ ). This means that the higher the patients' spiritual well-being, the higher their HRQoL. The indirect effect of spiritual well-being on illness perception and HRQoL is also significant $(\beta=0.7125, S E=0.2805, t=2.5404, p<$ 0.05 , lower-level confidence interval $=0.1461$, upper-level confidence interval $=1.2789$ ). This shows that illness perception partially mediated the relation between spiritual well-being and HRQoL. 
Table I. Demography

\begin{tabular}{|l|l|l|}
\hline Participants & Frequency & Percentage \\
\hline Female & 25 & $56.8 \%$ \\
\hline Male & 19 & $43.2 \%$ \\
\hline Heart Diseases & & \\
\hline Coronary Heart Disease & 15 & $34.09 \%$ \\
\hline Congestive Heart Failure & 2 & $4.54 \%$ \\
\hline Congenital Heart Disease & 1 & $2.27 \%$ \\
\hline Hypertensive Heart Disease & 6 & $13.63 \%$ \\
\hline Other CVD & 20 & $45.47 \%$ \\
\hline
\end{tabular}

Table II. Mediation Analysis from Spiritual Well-Being to HRQOL

\begin{tabular}{|l|c|c|c|c|c|}
\hline & $\boldsymbol{\beta}$ & $\boldsymbol{S E}$ & $\boldsymbol{t}$ & $\boldsymbol{p}$ & $\boldsymbol{R}^{2}$ \\
\hline SWB to IP & -0.0391 & 0.0187 & -2.0962 & 0.0421 & 0.947 \\
\hline IP to HRQoL & -4.7772 & 2.2069 & -2.1646 & 0.0363 & 0.281 \\
\hline SWB to HRQoL & 0.8993 & 0.2783 & 3.2313 & 0.0024 & 0.199 \\
\hline Total Effect & 0.8993 & 0.2783 & 3.2313 & 0.0024 & - \\
\hline Indirect Effect & 0.1868 & 0.1210 & - & - & - \\
\hline
\end{tabular}

Note. $\mathrm{SWB}=$ Spiritual well-being; IP = Illness perception; HRQL $=$ Health-related quality of life

\section{Discussion and Conclusion}

This study investigated the relation between spiritual well-being and HRQoL with illness perception as a mediating variable. The results found that spiritual well-being is a significant predictor of HRQoL. This confirms the findings of previous studies (Nelson et al., 2009; Jahani et al., 2013; Park et al., 2014; Pilger et al., 2017). However, the mediation analysis showed that illness perception partially mediated spiritual well-being and HRQoL. When patients are in a high state of spiritual well-being, they have faith and feel optimistic about their health. These two factors help patients mitigate their anxiety and depression. When patients have no anxiety and depression, they have good mental health, which means they have great HRQoL.

The findings also observed that illness perception does not contribute to spiritual well-being and HRQoL. Another factor was found to explain the relation between spiritual well-being and HRQoL. A previous study (Strada, Homel, Tennstedt, Billing, \& Portenoy, 2013) showed that a person's spiritual well-being directly affects their emotional response, such as anxiety. Future research would benefit from including anxiety or depression as mediators to analyze the relation between spiritual well-being and HRQoL.

These findings promote the importance of spiritual well-being in increasing patients' HRQoL. Our study showed that spiritual well-being is a significant predictor of HRQoL. Therefore, health workers must conduct spiritual interventions to enhance patients' HRQoL. These interventions have been done in Iran and have significantly reduced stress and depression and increased HRQoL in patients with chronic illness (Jafari et al., 2013; Hosseini, Kashani, Akbari, Akbari, \& Mehr, 2016). However, a limitation of this study is its small sample size, which may influence the mediation analysis (Suhardi, 2010). In further studies, a bigger sample 
size should be obtained so that the findings can be better generalized to the heart disease population.

\section{References}

Arnold, S., Herrick, L. M., Pankratz, V. S., \& Mueller, P. S. (2007). Spiritual well-being, emotional distress, and perception of health after a myocardial infarction. Internet Journal of Advanced Nursing Practice, 9.

Boyd, K. J., Murray, S. A., Kendall, M., Worth A., Frederick, B. T., \& Clausen, H. (2004). Living with advanced heart failure: A prospective, community based study of patients and their carers. European Journal of Heart Failure, 6, 585-591.

Broadbent, E., Petrie, K. J., Main, J., \& Weinman, J. (2006). The brief illness perceptions questionnaire. Journal of Psychosomatic Research, 60, 631-637.

Büssing, A., Janko, A., Baumann, K., Hvidt, N. C., \& Kopf, A. (2013). Spiritual needs among patients with chronic pain diseases and cancer living in a secular society. Pain Medicine, 14, 1362-1373.

Cella, D. F. (1994). Quality of life: Concepts and definition. Journal of Pain Symptom Management, 9, 186-192.

Ellison, C. W. (1983). Spiritual well-being: Conceptualization and measurement. Journal of Psychology and Theology, 11, 330-338.

Gierlaszynska, K., Pudlo, R., Jaworska, I., Byrczek-Godula, K., \& Gąsior, M. (2016). Tools for assessing quality of life in cardiology and cardiac surgery. Quality in Medicine, 13, 78-82.

Goodman, H., Firouzi, A., Banya, W., Lau-Walker, M., \& Cowie, M. R. (2013). Illness perception, self-care behaviour and quality of life of heart failure patients: a longitudinal questionnaire survey. International Journal of Nursing Studies, 50, 945-953.

Guyatt, G. H., Feeny, D. H., \& Patrick, D. L. (1993). Measuring health-related quality of life. Annals of Internal Medicine, 118, 622-629.

Heo, S., Lennie, T. A., Okoli, C., \& Moser, D. K. (2009). Quality of life in patients with heart failure: Ask the patients. Heart \& Lung: The Journal of Critical Care, 38, 100-108.

Hosseini, L., Kashani, F. L., Akbari, S., Akbari, M. E., Mehr, S. S. (2016). The Islamic Perspective of Spiritual Intervention Effectiveness on Bio-Psychological Health Displayed by Gene Expression in Breast Cancer Patients. Iranian Journal of Cancer, 9, e6360.

Jafari, N., Farajzadegan, Z., Zamani, A., Bahrami, F., Emami, H., Loghmani, A., \& Jafari, N. (2013). Spiritual therapy to improve the spiritual well-being of iranian women with breast cancer: a randomized controlled trial. Evidence-Based Complementary and Alternative Medicine.

Jahani, A., Rejeh, N., Heravi-Karimooi, M., Hadavi, A., Zayeri, F., \& Khatooni, A. R. (2013). The relationship between spiritual health and quality of life in patients with coronary artery disease. Islamic Life Center Health, 1, 17-21.

Mills, P. J., Redwine, L., Wilson, K., Pung, M. A., Chinh, K., Greenberg, B. H., \& Chopra, D. (2015). The role of gratitude in spiritual well-being in asymptomatic heart failure patients. Spiritual in Clinical Practice, 2, $5-17$.

Moryś, J. M., Bellwon, J., Höfer, S., Rynkiewicz, A., \& Gurchala, M. (2016). Archieves of Medical Science: AMS, $1 ; 12,326-333$.

Nelson, C. J., Jacobson, C. M., Weinberger, M. I., Bhaskaran, V., Rosenfeld, B., Breitbart, W., \& Roth, A. (2009). The role of spirituality in the relationship between religiosity and depression in prostate cancer patients. Annals of Behavioral Medicine, 38, 105-114.

Thompson, D. R., \& Yu, C. (2003). Quality of life in patients with coronary heart disease-I: Assessment tools. Health and Quality of Life Outcomes, 1, 1-5.

Panzini, R. G., Mosqueiro, B. P., Zimpel, R. R., Bandeira, D. R., Rocha, N. S., \& Fleck, M. P. (2017). Quality of life and spirituality. International Review of Psychiatry, 29, 263-282.

Park, C. L., Aldwin, C. M., Choun, S., George, L., Suresh, D. P., \& Bliss D. (2016). Spiritual peace predicts 5year mortality in congestive heart failure patients. Health Psychology, 35, 203-210. 
Park, C. L., Lim, H., Newlon, M., Suresh, D. P., \& Bliss, D. E. (2014). Dimensions of religiousness and spirituality as predictors of well-being in advanced chronic heart failure patients. Journal of Religion and Health, 53, 579-590.

Petrie, K. J., \& Weinman, J. (2006). Why illness perceptions matter. Clinical Medicine, 6, 536-539.

Pilger, C., Santos, R. O. P. D., Lentsck, M. H., Marques, S., \& Kusumota, L. (2017). Spiritual well-being and quality of life of older adults in hemodialysis. Revista Brasileira de Enfermagem, 70, 689-696.

Reig-Ferrer, A., Arenas, M. D., Ferrer-Cascales, R., Fernández-Pascual, M. D., Albaladejo-Blázquez, N., Gil, M. T., \& de la Fuente, V. (2012). Evaluation of spiritual well-being in haemodialysis patients.Nefrologia, 32, 731-742.

Schnall, E., Wassertheil-Smoller, S., Swencionis, C., Zemon, V., Tinker, L., O'Sullivan, M. J., \& Goodwin, M. (2010). The relationship between religion and cardiovascular outcomes and all-cause mortality in the women's health initiative observational study. Psychology and Health, 25, 249-263.

Stafford, L., Berk, M., \& Jackson, H. J. (2009). Are illness perceptions about coronary artery disease predictive of depression and quality of life outcomes? Journal of Psychosomatic Research, 66, 211-220.

Strada, E. A., Homel, P., Tennstedt, S., Billings, J. A., \& Portenoy, R. K. (2013). Spiritual well-being in patients with advanced heart and lung disease. Palliative and Supportive Care, 11, 205-213.

Suhardi, D. A. (2010). Beberapa konsekuensi situasi mediasi sempurna pada struktur korelasi, kontribusi mediator, dan ukuran ampel. Retrieved from jurnal.ut.ac.id/index.php/JMST/article/download/479/408.

Ware Jr., J., Kosinski, M., \& Keller, S. D. (1996). A 12-item short-form health survey: construction of scales and preliminary tests of reliability and validity. Medical Care, 34, 220-233.

Webster, K., Cella, D., \& Yost, K. (2003). The function assessment of chronic illness therapy (FACIT) measurement system: Properties, application, and interpretation. Health and Quality of Life Outcome, 1, 79. 